\title{
Innovaatiokyvyn edellytyksiin pitää sijoittaa
}

\author{
Reijo Laukkanen
}

$\mathrm{Son}_{\mathrm{n}}^{\mathrm{u}}$ uomi kuuluu maihin, joissa OECD:n mukaan n viime vuosina kyetty lisäämään tuottavuutta nopeilla innovatiivisilla ratkaisuilla (Science, technology and industry outlook 2000). Kasvua on saanut aikaan erityisesti informaatio- ja kommunikaatioteknologian käytön lisääminen, mihin on yhdistetty tuotannon järjestämistavan muutoksia ja entistä parempaa työntekijöiden osaamista. Erityisenä voimana on ollut vahva luottamus tutkimukseen ja tuotekehittelyyn.

Tutkimus- ja tuotekehitystyöhön panostaminen kasvaa, mutta eri maissa siihen käytetään rahaa eri määrin. Lähes puolet koko OECD-alueen tieteellisen tutkimuksen ja teknologisen kehitystyön rahoitusmassasta on Yhdysvalloissa. Tällaisissa vertailuissa Suomi ymmärrettävästi ei voi menestyä hyvin, mutta kun katsotaan, miten paljon sijoitamme varallisuudestamme, menestyksemme tuottavuuden lisäämisessä tulee hyvin näkyviin. Suhteessa bruttokansantuotteeseen sijoitamme tutkimukseen (R \& D) Ruotsin jälkeen toiseksi eniten koko OECD:ssä, ja jälkeemme tulevat Japani, Etelä-Korea, Sveitsi ja Yhdysvallat. Sijoitamme siis korkean tason osaamiseen. Kun tiedosta ja inhimillisestä pääomasta on muodostunut yrityksille vähintään yhtä tärkeä tekijä kuin taloudellisesta pääomasta, niiden on huolehdittava henkilöstönsä osaamisesta ja saatavuudesta. Tämä edellyttää myös yhteiskunnan julkisen sektorin panostusta. Tiede- ja teknologiaalan henkilöstön kysyntä on jatkuvasti kasvanut. Yhteiskunnan vastuulla on koulutusjärjestelmäkoulutuksen, tutkimuksen edellytysten ja osaamisen varmistaminen (Mobilising human resources for innovation, OECD 2000).

Osaajien työmarkkinat ovat muuttuneet. Suurin osa tutkijoista työskentelee yksityissektorilla, josta myös tulee suurin osa maiden tutkimusvaroista. Yhdysvalloissa yksityissektori työllistää 80 prosenttia tutkijoista. Myös työehdot ovat muuttumassa. Yritykset palkkaavat tutkimus- ja kehitystyöhön yhä enemmän tilapäistä työvoimaa. Sama näkyy joissakin maissa myös julkishallinnon rahoittamissa tutkimuslaitoksissa. Esimerkiksi Japanin julkisten tutkimuslaitosten työntekijöistä suuri osa työskentelee osa-aikaisesti tilapäisissä työsuhteissa.

Teollisen tutkimus- ja kehitystyön globalisoitumisesta ja korkeakoulujen laajentuneesta kansainvälistymisestä on seurannut kilpailua osaajista. Viime vuosikymmenen viimeisen puoliskon kaikista Silicon Valleyn uusista yrityksistä 30 prosenttia oli kiinalaisten ja intialaisten siirtolaisten perustamia. Vastaavasti lähes sama osuus kaikista Yhdysvaltain tohtoritason tiede- ja teknologiaalan työntekijöistä oli muualla syntyneitä. Nämä tosiasiat tulevat ymmärrettäviksi myös katsomalla siirtolaisuustilastoja (Trends in international migration, OECD 2001). Tutkijoiden ja muun korkeasti koulutetun henkilöstön liikkuvuus alkaa olla monella tavalla innovaatiojärjestelmiä hyödyttävä tosiasia. Tähän tietotalouden tuomaan työmarkkinoiden kansainvälistymisen haasteeseen pitäisi kiireesti valmistautua myös Suomessa. Miten yrityksille turvataan tutkijavoimia? Miten houkuttelemme osaajia muualta ja pidämme kiinni omistamme?

Tietotaloudesta on monia määritelmiä. Yksi voisi olla, että sillä tarkoitetaan taloutta, jossa yritykset, organisaatiot, ihmiset ja yhteisöt luovat, hankkivat, välittävät ja käyttävät tietoa tehokkaasti taloudellisen ja sosiaalisen kehityksen ai- 
kaansaamiseksi (Korea and the knowledge-based economy, OECD 2000). Tiedolla tarkoitetaan sekä kodifioitua että ihmisten omaamaa ns. hiljaista tietoa. Viimeistään hiljaisen tiedon tuoma osaaminen tekee tärkeäksi yksittäiset ihmiset. Työntekijöiden koneellinen vaihtaminen ei ole organisaatioiden edun mukaista.

$\mathrm{T}$ ieto pitäisi saada liikkeelle. Muodikas tietojohtamisen filosofia pureutuu tähän. Jaettu tieto tuo valtaa. Organisaatio hyötyy, jos yksittäisten ihmisten tieto saadaan koko organisaation käyttöön. Asia on ymmärretty monessa organisaatiossa kerrassaan väärin. Organisaatiot ovat hukkumassa informaatiotulvaan. Kaikille tulee kaikkea, eikä informaatio löydä niitä, jotka sitä tarvitsisivat, eivätkä tarvitsijat löydä tietoa. Organisaatioiden tiedonhallinnalle muodostuu suuri haaste seuloa ja jakaa tietoa sekä ohjata sen lähteille nykyistä täsmällisemmin. Organisaatioiden pitäisi pystyä käyttämään tietoa tehokkaasti.

Organisaatioiden oppimisessa on olennaista niiden sisäinen ja keskinäinen vuorovaikutus. Sama koskee innovaatiojärjestelmiä, jotka muodostuvat innovaatioita kehittävistä, levittävistä ja käyttävistä organisaatioista sekä niiden keskinäisistä suhteista (Cities and regions in the learning economy, OECD 2000). Varmasti yksi keskeisistä tekijöistä Suomen menestykseen on ollut se, että kansalliseen innovaatiojärjestelmään jo pitkään panostamalla on voitu luoda osaamiskapasiteettia. Eri politiikkasektoreiden yhteistoimilla on lisätty osaamista ja kannustettu yhteistyöhön. Koulutussektorimme erityisinä suorituksina voidaan mainita ammattikorkeakoulujärjestelmän pystyttäminen ja tohtorintutkintojen määrän nopea kaksinkertaistaminen. Tiedepolitiikan puolelta on tärkeää kirjata tutkimusrahoituksemme maailmanennätyksellinen nosto yhdeksänkymmentäluvun loppupuoliskolla. Nyt puhutaan alueellisista innovaatiojärjestelmistä, mutta niistäkin meillä on jo paljon osaamista.

Y lhäältä on helppo pudota. Olisi vastuuntunnotonta ajatella, että nyt kaikki tälleensä turvaa myönteisen kehityksemme myös jatkossa. Osaaminen tuotantomme ydinalueilla on välttämätöntä varmistaa, mutta silti kaikkia munia ei pitäisi panna yhteen koriin. Kapasiteetin rakentamisesta pitäisi huolehtia laajemmin. Eri alojen perustutkimusta pitäisi voida varmistaa, sillä irtiottoja uusilla aloilla saatetaan tarvita. Tämä on myös tämän hetken huippuosaamisalojemme etu, sillä panostaminen vain lyhytaikaista hyötyä tuovaan tutkimukseen näivettää uusien mahdollisuuksien löytämisen. Tärkeä peruste tulee myös siitä, että yhteiskunta ei ole vain tekniikkaa ja taloutta, joten edistymistä tarvitaan muillakin aloilla.

Perustutkimuksesta huolehtimisen välttämättömyydestä OECD huomautti myös Etelä-Korealle. Tärkeä sanoma sille oli myös, että inhimillisestä pääomasta vastaavan apulaispääministerin toimialue pitäisi laajentaa opetusministeriön hallinnonalasta inhimillisten resurssien varmistamiseen kaikilla hallinnonaloilla. Tämän vuoden alussa kritiikkiin reagoitiin laajentamalla opetusministeriön toimialaa. Kysymys on erityisesti aikuiskoulutuksen koordinoidusta toteutuksesta.

Perustellusti moni väittää, että seuraava suuri vallankumous tapahtuu bioteknologian alalla. Laajimmin sivistykseen ja hyvinvointiin vaikuttaisi kuitenkin vallankumous, joka todentaisi elinikäisen oppimisen. Se voisi nostaa taloudellista ja sosiaalista hyvinvointia rajusti.

Kirjoittaja työskentelee Suomen Pysyvässä OECD-edustajistossa Pariisissa erityisasiantuntijana. 